\title{
The social exploits and behaviour of nurses during the Anglo-Boer War, 1899-1902 ${ }^{1}$
}

\section{Charlotte Dale}

During the Second Anglo-Boer War, two key watchwords associated with serving nurses were 'duty' and 'respectability.' At the commencement of war, women from across the Empire, including trained nurses, saw the opportunity to travel to South Africa to experience war and work alongside men as their equals, caught up in a patriotic fervour to defend and expand the Queen's lands. The war, which resulted from years of ambitious encounters over gold deposits, Afrikaner expansionism and continued conflict between long-term settlers in South Africa and newly arrived British subjects, had an inevitability about it. ${ }^{3}$ Conflict had followed conflict in the previous two decades as Britain attempted to expand its Empire and take control of the rich mineral fields of southern Africa, fighting first the Zulus (in the first Anglo-Zulu War of 1879) and then the Boers, in the first Anglo-Boer War of 1880-81. A series of smaller skirmishes followed, culminating in the Second Anglo-Boer War (1899-1902) at the end of the century. ${ }^{4}$

This chapter will reveal the weaknesses in the organisation of military nursing at this time and the disciplinary problems resulting from the presence of large numbers of young women, detached from social bonds which maintained their behaviour within acceptable limits. It provides an insight into the social exploits and experiences of nurses during the Second Anglo-Boer War and illustrates societal expectations of moral conduct and the impact accusations of 'frivolous' behaviour had on the views of both the medical authorities and nurses themselves. In this specific colonial context, also referred to by Angharad Fletcher in Chapter 2, nursing was being provided across 
(what was to become) 'South Africa' by a number of different agencies which have been described as 'reflecting the disjointed course of colonial development [in South Africa].' This 'nursing' included care by family members and traditional healers for much of the indigenous population, the basic nursing and medical knowledge of European missionaries, the presence of trained European nurses, as well as the Afrikaners' and their servants' own home remedies and nursing methods. Furthermore, Indian immigrants, 'brought with them their own systems of medicine and associated beliefs and practices, including Ayurvedic medicine, Siddha, massage, a vast range of herbs, oils and spices and even a variant of Acupuncture. ${ }^{6}$ Rather than viewing military and military-associated nursing in isolation it should be appreciated therefore that nursing in the Boer War needed to navigate this gamut of systems.

Furthermore, the nurses who came to support the military at the outbreak of the Second Anglo-Boer War were at the forefront of a vocation that had a particular need to assert itself as a 'profession', reflected in the fact that South Africa was the first country to introduce state registration. ${ }^{7}$ Keiron Spires has shown that these same women were mostly 'ordinary nurses who wanted the experience and challenge of working in South Africa, or who were caught up in the conflict and continued to nurse the sick and wounded under new circumstances. ${ }^{8}$ His research demonstrated their 'relative youth and inexperience and the lack of a nursing structure within which to practice. And yet, as Anne Marie Rafferty has pointed out, these relatively inexperienced and naive 'new nurses' who were 'charged with a civilising mission at home' were sent to the colonies where they became 'bearers of that same mission across a great expanse of empire.' Such nurses were to play a crucial role in winning the confidence of indigenous communities, and the decorum and demeanor of the nurse was her most powerful tool in asserting her authority over the 'native personnel. ${ }^{10}$ This chapter will examine how this expectation of nurses to be couriers of the colonial project was challenged by the poor organisational structures in place at the beginning of the Boer War and how the Boer War experience led to a complete overhaul of the structure and management of military nursing and nurses in wars to come.

The importance of good military nursing first emerged following the medical atrocities of the Crimean War and the widespread 
acknowledgement of Florence Nightingale's nursing endeavours. In 1857, in the wake of that war, the Army Sanitary Commission proposed that trained female nurses should be introduced into Army hospitals. These nurses would take charge of and be responsible for patients' cleanliness and nourishment, attend to minor dressings and administer medications, all under the orders of the Medical Officer. ${ }^{11}$ Anticipating the problems which might arise if young men and women were to join together in the armed services, Nightingale recommended that only women deemed to be of appropriate character and with previous experience as head nurses should be proposed as candidates; only such women could be trusted to behave respectably, as, she claimed, 'misconduct in women is more pernicious in a military hospital than any other. ${ }^{12}$ After persuasive lobbying from Nightingale and her supporters, and despite strong opposition from the military, a small Army Nursing Service (ANS) was established in 1861. But it failed to thrive, and the Army reverted, for the most part, to its old system of male orderlies. ${ }^{13}$

In the following decade, as need dictated, small numbers of female nurses were recruited into the service of the Army, and accompanied them on the various African campaigns, including those in Egypt and Sudan in the 1870s and early 1880s. Fourteen nurses served during the Anglo-Zulu War of 1879, but it was not until 1881 that the call for a more formal Army nursing service was revived. It was proposed that the National Society for Aid of the Sick and Wounded in War (also known as the National Aid Society and the forerunner of the British Red Cross) would provide training for nurses destined to support the Army during times of conflict. ${ }^{14}$ This initiative marked the rebirth of the Army nursing service, with a code of regulations for a 'Female Nursing Service' published in 1884. However, the full implementation of the National Aid Society's original plans, which included the creation of a reserve of nurses trained in military nursing, did not take place, hampered by a lack of space in military hospitals in which to accommodate such nurses in times of peace. ${ }^{15}$ By 1897, though, it was accepted that the existing ANS, which consisted of one Lady Superintendent, nine Superintendents and sixty Nursing Sisters, was totally inadequate to serve the needs of the armed forces in the event of large-scale war. ${ }^{16}$ This led to the establishment of the Army Nursing Service Reserve, with Princess Christian, Queen Victoria's daughter, 
as its president (henceforth PCANSR). ${ }^{17}$ Its aim was to guarantee sufficient numbers of trained nursing staff in the event of war, while preventing an influx of unqualified volunteers, such as the lady war tourists' who had meddled in the nursing management during the Crimean War. ${ }^{18}$

The establishment of the PCANSR was not universally welcomed: at least one national newspaper charged that wartime service held a 'rather romantic glamour' whereby an 'average nurse' could experience the realities of war, from the comparative safety of the base camp. ${ }^{19}$ Nevertheless, whether nurses felt it their duty to serve as patriotic members of the wider Empire, or desired to participate in the 'romantic glamour' of wartime service, hundreds of female nurses were enlisted into the Reserve during the three-year period of the Second Anglo-Boer War. Against a background of growing patriotic jingoism and a sense of duty to Queen and Empire, it is perhaps unsurprising that so many British nurses, and women in general, wished to 'do their bit. ${ }^{20} \mathrm{~A}$ further motivation for some nurses may have been the lure of public recognition: the Royal Red Cross (RRC), inaugurated in 1883 , was a prestigious award that provided nurses with tangible evidence of their service. It allowed recipients to place themselves alongside Florence Nightingale and other 'heroic' recipients such as Nurse Catherine Grace Loch, of the Indian Army, and Sister Janet King, who had served during the Anglo-Zulu War. ${ }^{21}$ Historically, female nurses have been motivated for a variety of reasons to engage in military campaigns: as historian Jane Schultz illustrates in the case of the American Civil War, women were 'moved variously by patriotism, self-sacrifice' and of course in a search for adventure. ${ }^{22}$ At the commencement of the Second Anglo-Boer War in 1899, female nurses were also attracted to wartime service by the increased opportunities it offered to travel unchaperoned and to experience the theatre of war, with less censure than that received by their predecessors. ${ }^{23}$

Nevertheless, those women enlisting for wartime service who were tempted by the prospect of opportunities for travel and social exploits alone were condemned by many of their peers and by the general public as 'frivolous. ${ }^{24}$ In this period, an era heavily steeped in social ideals concerning the respectability and suitable role of women in society, a woman who behaved in such a manner risked her own reputation (and respectability) and also that of her family and her institution. ${ }^{25}$ 
According to contemporary rhetoric, there were only two types of nurse: the 'good nurse', presented as a self-sacrificing angel, a woman ready to deny all in her dedication to those within her care; or her polar opposite, the 'bad nurse'. This was a woman willing to abuse her position of 'power and authority' for her own means. This depiction of nurses as either 'good' or 'bad' reflects the Victorian rhetorical device of dichotomies, where, as Juliet Hallam points out, nurses are situated within the 'virgin/whore dichotomy. ${ }^{26}$ So influential was this discourse that it continued through the First and Second World Wars, when nurses were often depicted as 'sexless white angels' or as 'predatory' and 'highly sexualised' women who preyed on officers or doctors in search of an advantageous marriage. ${ }^{27}$

It should be recalled, that back in England at the end of the nineteenth century, the battle for state recognition and control of nursing was being waged with government, the medical profession and within the body of nursing itself. It was imperative for nursing leaders to ensure that the 'good nurse' image was not only protected, but that it dominated public discourse. While there was no central control over the practice of nursing (no national standardised training or systems of examination were in place) and in theory anyone could call themselves a 'nurse', in practice all large hospitals (and most small ones by the end of the century) provided some level of training and certification for their probationary nurses. ${ }^{28}$ Nevertheless, this essentially unregulated environment created an ambiguity regarding the position of nurses and news of 'frivolling women' acting as nurses from southern Africa would do nothing to promote the cause. ${ }^{29}$ Furthermore, the nurses who served in southern Africa came from across the British Empire, and British nurses, both military and civilian, found themselves working alongside nurses from the colonies, some of whom had already attained registration. The British nurses would have been acutely aware that the heritage of nursing within the colonies was instigated by their predecessors, who went out to support and establish the first schools of nursing. The fact that many of these nurses from outposts of the Empire, such as New Zealand and South Africa, had achieved through registration what the British nurses had so far failed to do must have rankled. ${ }^{30}$ Minnie Goodnow has argued that although England was in a class of its own as a 'great leader' in nursing practice and innovation, and that 'the world ... followed her move', 
yet in respect of registration Britain was not at the forefront, other British Dominions were winning the battle for professional recognition ahead of the mother country. ${ }^{31}$ Anne Marie Rafferty observes that leaders such as Ethel Fenwick, who spearheaded the registration movement in Britain, used the achievement of registration in British dominions as further support for her arguments for nurse registration in Britain. ${ }^{32}$ Paradoxically, the Cape Colony in southern Africa was the first part of the British Empire to introduce a form of nurse registration, in the late nineteenth century. ${ }^{33}$ It was therefore feared that detrimental allegations of bad behaviour by nurses in South Africa might have a negative impact on the drive for registration at home.

The behaviour and respectability of British nurses, therefore, came under close scrutiny during the Second Anglo-Boer War, starting as soon as they boarded their ships. Princess Christian entreated the senior nurses who were travelling out to South Africa with the nursing corps to act as moral supervisors over their junior nurses and to provide reports on those who did not behave appropriately, to both the head of the Red Cross and to Princess Christian herself. ${ }^{34}$ While ensconced in the relative safety of the ship, it was possible to exert strict control over the nurses, but this was no longer possible on landing in South Africa, where numerous opportunities for the nurses to 'frivol' opened up. ${ }^{35}$ Later, during the Royal Commission of 1901 into the reorganisation of the Army nursing service, part of the blame for this lack of control was put on weaknesses in its organisation, and particularly a lack of leadership of the nurses in South Africa. The problem lay in the structure of this nascent Army nursing service. Its Lady Superintendent was based at Netley in the UK, thousands of miles from the nurses over whom she wielded authority; and that authority was further diminished by her position in the Army hierarchy relative to her male counterparts. ${ }^{36}$ As a consequence lines of command were weak and unclear.

On arrival in South Africa, the majority of British and colonial nurses from Australia, New Zealand and Canada were based in military camps or garrisons caring for wounded or sick soldiers of the Empire. Increasingly, however, some found themselves assigned to the concentration camps established by the British, initially for Boer refugees fleeing from the fighting. As the camps grew in size and number, as a result of the British 'scorched-earth' policy adopted in 1901 which saw Boer 
families burned out of their homes and their farms destroyed to cut the supply lines to the Boer fighters, demand for nurses in these desperate places became more and more pressing. ${ }^{37}$ Africans attempting to escape the fighting were also caught up in the 'scorched-earth' policy and were interred, in separate camps. Disease was rife within the camps, with high numbers succumbing to measles, typhoid and pneumonia. ${ }^{38}$ Concerns were raised in Britain by social reformers such as the radical liberal Emily Hobhouse over living standards in the camps and the lack of medical care. ${ }^{39}$ There were insufficient doctors and nurses to properly staff the camps, and priority was given to the care of British and Empire soldiers. ${ }^{40}$ Following outcry in the press and in response to reports raised by Hobhouse and others over standards of care in the camps, a large-scale recruitment campaign commenced, with approximately a hundred nurses joining up, many from Scotland..$^{41}$ As Elizabeth van Heyningen has explained, they came for a variety of reasons, including 'a sense of adventure', but also (and perhaps more importantly) for financial reward, as the pay was superior to that in Britain. ${ }^{42}$ However, while van Heyningen has revealed new evidence in her most recent book on the experiences of life in the camps, she has found little relating to the doctors and nurses who worked in them, making a discussion of the social life of nurses who worked in the camps, in comparison to the military hospitals, beyond the scope of this chapter. ${ }^{43}$

The main medical challenge facing newly arrived nurses and doctors was not, as might be expected, the care of the seriously wounded but, rather, the challenges created by conditions in the military camps of poor sanitation and overcrowding. Morbidity studies of serving soldiers reveal that typhoid fever was the most prominent of all diseases and featured regularly in nurses' personal testimonies and in the wider nursing press. ${ }^{44}$ Although typhoid was not the only disease affecting the troops, their living conditions and general poor health left them particularly vulnerable to outbreaks of this disease.$^{45}$ In the absence of any pharmaceutical tools with which to tackle typhoid, careful nursing was the key to successful treatment, a fact well known and recorded by doctors. For example, Dr A. Knyvett Gordon, writing in the Nursing Record in 1901, acknowledged that 'the recovery of the [typhoid] patient depends not so much on the prescribing of any particular drug, or line of treatment as on the way in which the treatment is carried out - that is to say, the efficiency of the nursing. ${ }^{46}$ 
It is clear that alongside their clinical duties, nurses also had the opportunity to participate in a varied and active social life despite the high demands of caring for the Army's sick and wounded. In Bloemfontein, where an epidemic of typhoid fever was raging through the ranks, Nurse Dora Harris chronicled in her diary the many social events she had attended, despite the overwhelming numbers of typhoid cases to be nursed. Although exhausted after a demanding shift nursing typhoid patients, she recalled one night staying up until midnight making a fancy-dress outfit for a 'Variety Race' she had been invited to the next day:

In the afternoon Sister's Friend, Ross, Smyth and I went to Bloemfontein to buy material for fancy dresses for the Variety Race, and we sat up till 12 making them. The most absurd is the ballet girl's - pink tarlatan and roses. Mine is a Japanese Kimono, and the other two a clown and [a] baby. ${ }^{47}$

After the success of the fancy dress 'Variety Race' and during a period of night duty, Harris persuaded another nurse to cover her duties until 3 a.m. so that she could attend a local English colonists' dance, leaving at 2 a.m. to complete her duty. It seems she did not even stop to change into civilian clothes, claiming to have proudly worn her nurse's uniform while indulging in 'plenty of dancing' and enjoying herself 'immensely' as it 'was very jolly. ${ }^{48}$ During their service in South Africa, nurses recorded their many varied excursions in their personal correspondence. They recorded their daily opportunities for riding or how they spent their off-duty hours in learning to ride. They attended regular musical concerts within camps or in local towns, croquet and polo parties and went on numerous picnics across the veldt, in addition to afternoons spent rowing with medical officers, before participating in games of cricket and hockey. ${ }^{49}$ Emily Wood, a Scottish Reserve nurse based at the Royal Red Cross Hospital in Kroonstad, proudly wrote to her family that she had formed part of the nurses' team pitted against the hospital's male cricket team, before going on an outing to the zoo to see the springboks. ${ }^{50}$ On another occasion she was invited to attend a 'Cinderella Dance'. In preparation for the dance, she wrote in her journal:

On Monday I had to buy a pair of white silk gloves 3/-, plus a pair of fancy slippers $8 / 6$ plus some lace for fancy capes, the Colonel having given his 
sanction to our going to the Cinderella Dance at the Kroonstad Hotel.

[However] we were not allowed to wear our scarlet capes. ${ }^{51}$

Although the nurses discussed in this chapter regularly described their social exploits in their diaries, they also commented on their working lives and the hardships of working life in South Africa. It is clear many nurses worked long and arduous hours, but there were disparities owing to a lack of overall authority over the various groups of nurses. PCANSR nurse Edith Hancock recorded that following a long and tiresome journey to her nursing assignment she was required to reside in less than salubrious surroundings. Hancock wrote on arrival at Green Point that the work 'was killing', owing to a lack of equipment and suitable accommodation as there were 'no extras, barely necessities, which made it much harder - we had to pig it no end in our own quarters too - we were so cramped and the only place to cook, a small open fireplace. ${ }^{52}$ Opportunities to participate in social encounters may well have offered light relief from the everyday trials of camp life. Like the women who followed the Army in campaigns such as the Crimean War, the women and nurses of the Anglo-Boer War were required to endure and adapt to insalubrious and often insanitary conditions with few complaints. ${ }^{53}$ The social events described with such relish by nurses may have helped them to 'escape' their daily hard work, while continued praise and public acknowledgement of their uncomplaining acceptance of arduous conditions encountered in the course of providing a humanitarian service to the sick and wounded would have raised their professional confidence, and challenged the perception that women were physically inferior. ${ }^{54}$

Nevertheless, not all nurses were seeking opportunities for social exploits during their wartime service. Ethel Becher, who by the First World War had been promoted to Matron-in-Chief of the Queen Alexandra's Imperial Military Nursing Service, had left her position at The London Hospital in December 1899 to enlist as a Reserve nurse. ${ }^{55}$ Eager to distance herself from accusations of 'frivolling', Becher wrote to Sydney Holland, chairman of The London Hospital House Committee, to assure him that his nurses were maintaining the respectable image of his hospital, demonstrating impeccable behaviour while in South Africa. She wrote, 'of course we have in many circumstances refused to go to picnics, riding and driving parties in company with many khaki clad young men.5 ${ }^{56}$ She makes clear in the 


\section{Nurses during the Anglo-Boer War}

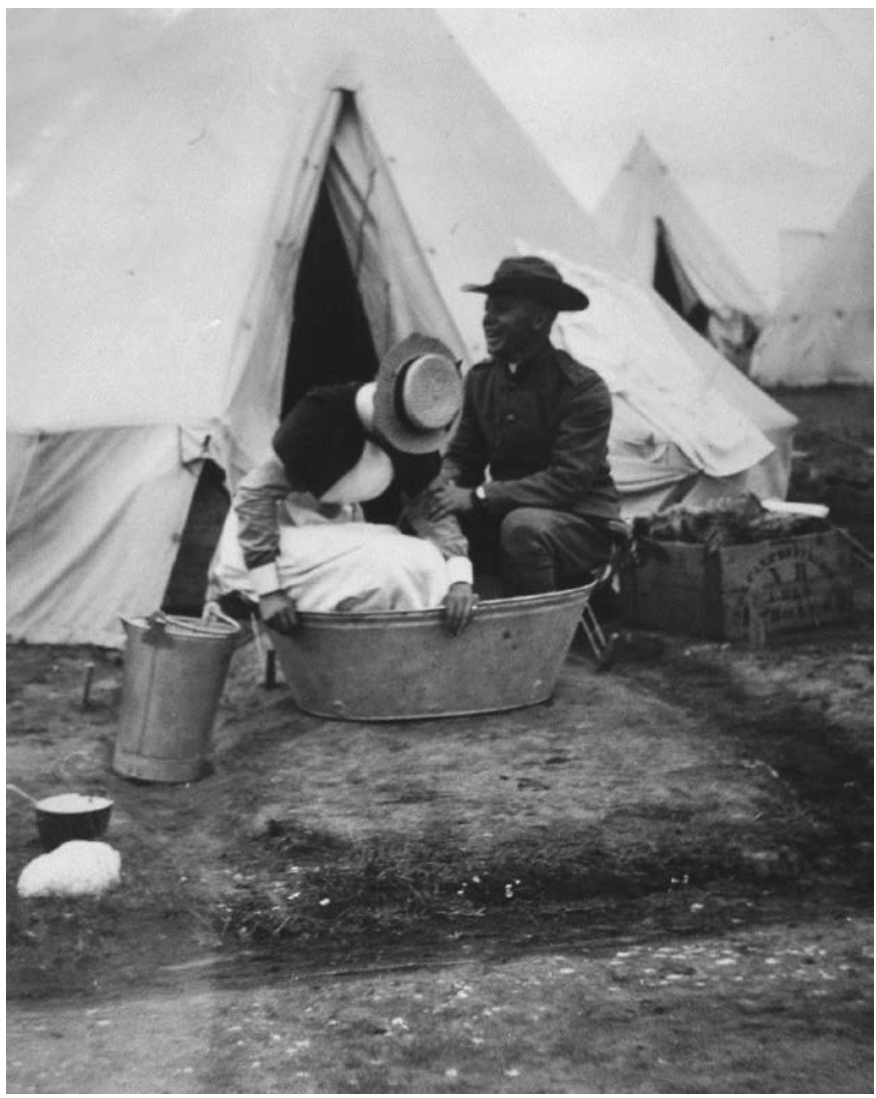

3.1 'Two in a tub', Estcourt 1900

same letter her disillusionment at the behaviour of some of her nursing colleagues and the potential damage they did to the reputation of nurses generally:

We are associated in every way with a body of women so many of whom one feels ashamed to think were ever nurses, in fact I have been tempted to wish I had never come out to be mixed up in the mind of the public with such a collection. ${ }^{57}$

Fellow Reserve nurse Eleanor Laurence also recorded her distaste at the behaviour of some her nursing colleagues, recounting in a letter 
written at the General Hospital, Natal in 1901 that twelve of her fellow nurses had attended a 'big dance', and on another night had gone to 'some theatricals' which in Laurence's opinion seemed to be 'festivities' that were

a little out of place while the war is going on. Some of the sisters appear to think that they have come out here to have as much fun as they can get, and talk about very little except the men they have been dancing with, and so on. ${ }^{58}$

Laurence remarked how, at first, the nurses had been allowed to attend dances and riding picnics with soldiers, until their conduct began to be talked of in an unfavourable manner. ${ }^{59}$ As a result of the disquiet surrounding such behaviour, the nurses had been provided with 'rules to conduct', rules that Laurence felt it should not have been necessary to issue to a lady. But unladylike behaviour did occur and Laurence was aware of a colleague who had been seen at a local station hotel 'smoking a cigarette with a most undesirable companion!'. ${ }^{60}$ The issue bothered her, and she returned to it again, stating that though there are plenty of sisters out here who are working hard and well, they will probably all get classed together in the public estimation with those who are simply "frivolling" and getting themselves talked about. ${ }^{\text {'1 }}$ With respectability identified as a 'Victorian watchword', and despite the fact that by the end of the century more women were moving into the public sphere to take up employment, the close proximity of unchaperoned women to a large body of men challenged ideals of Victorian respectability. ${ }^{62}$ There was an expectation that women would not be 'open' with men or allude to heterosexual feeling, nor were they expected to consort unchaperoned without risk to their 'good name. ${ }^{3}$ Prevalent views of the period held that young women should be 'both sexually unawakened and inviolable', and were at risk of corruption by close contact with men. ${ }^{64}$ These views account for the censuring of female nurses who appeared to revel in this inappropriate proximity ${ }^{65}$ Rafferty has observed such censure in her study of the Colonial Nursing Association, where 'The highly regulated and scrutinised order of [nurses' lives] as representatives of the empire meant any breach of the codes of conduct were met with stern criticism at best, and at worst the termination of their position as a CNA nurse. 66 
The position of women in British society at the end of the nineteenth century was on the cusp of significant change: access to the workplace was increasing, more women were going out into the world and working alongside men (although often in gender-segregated spaces) and access to higher education was improving. Politically, the emergence of the 'new woman', promoted by the growing feminist/suffrage movement, was making significant challenges to the assumptions and mores of the earlier Victorian period. In this environment it seems only natural that some women would view an opportunity to travel to places like South Africa as a way of speeding up this process. ${ }^{67}$ The idealised 'new woman' may have expected to go 'wherever she pleased without a chaperone', yet it is apparent that some nurses, such as Ethel Becher and Eleanor Laurence, found close social contact with male colleagues a source of discomfort for them and raised fears over personal respectability.

The preservation of respectability was also a consideration for Katharine Nisbet, matron of the voluntary Imperial Yeomanry Hospital in Pretoria, when rumours began to circulate that she had become engaged to a man, whom she claimed never to have actually met. ${ }^{68}$ Eager to quash the rumours and preserve her reputation, Nisbet wrote to her fiancé, who was on a posting to Egypt, that she had heard that the man in question was already engaged to another nursing sister, who in turn had boasted to Nisbet that this was her ' 5 th since coming out' and had declared that she was anyway already 'engaged to someone at home. ${ }^{69}$ Nisbet was anxious to ascertain what her fiancés family thought of nurses, as she claimed, 'If I heard the mere fact with no particulars that a brother of mine was engaged to a nurse, call her a Sister or a Matron or anything you like, I should be dreadfully worried till I knew what she was like. ${ }^{70}$ Nisbet was worried that some nurses were 'improved so immensely by uniform ... [and] by the regular rules of hospital life', but if just 'one in 100 is socially or any other "ally" [not] quite all right' then the reputation of all nurses was tarnished: just because a woman held the title of nurse and wore a uniform did not mean they were respectable. ${ }^{71}$ The worrisome behaviour of some nurses in South Africa was further pondered by Nisbet in another letter sent some months later, reporting that her brother had

told us terrible tales of the hospitals at Bloemfontein. He says he has been ashamed to own to having a sister nursing out here. Round where he is they 
have a horror of the whole thing, hospitals [and] all connected with them [and] to be a nursing sister is tantamount to being no longer a respectable member of society. Isn't it terrible to think such things can be .... They say it is the scandal of South Africa. ${ }^{72}$

Nisbet was fully aware of the ramifications for all nurses' perceived sense of propriety, with respectability contemporaneously understood as a style of living that demonstrated 'a proper respect for morals and morality. ${ }^{73}$ She appeared eager to reassure her new fiancé of her personal distaste for such behaviour; as a future wife she would have been expected to serve as her husband's 'helpmeet' and, as Patricia Branca states, to 'provide the proper environment of respectability. ${ }^{74}$ In this letter, Nisbet is merely reflecting the fears of nursing leaders and educators of the period, that such behaviour would encourage society to view nurses as anything but 'self-sacrificing angel[s] $\cdot^{75}$ Eva Luckes, matron of The London Hospital and author of training texts for nurses, echoed these fears:

Think of the harm that is done if a nurse gives one man cause to think and speak worse of women than before he entered the hospital! Every nurse should remember that it depends upon herself, rather than upon the men with whom she comes in contact, whether they will ultimately leave the hospital declaring that they would not have their sisters enter upon such a life for all the world. ${ }^{76}$

It is apparent that men were not generally held accountable for a woman's fall from grace; rather, the responsibility lay with the woman to protect her own reputation. For nurses, it could be argued, the need was even greater as not only her own reputation was at stake but also the high 'measure of public distinction', in which nursing as a whole was held. ${ }^{77}$ If nurses were discovered to have enlisted for wartime service with the sole aim of excitement and social pleasures, there would be an increased risk of 'nursing scandals' reaching the public back home and further challenges to the desire to shape nursing as a respectable and professional occupation for young women. ${ }^{78}$

Such concerns, over the appropriate behaviour and the perceived respectability of nurses, were central to discussions in the War Office Committee, which had been given the task in 1901 of reorganising the Army nursing services. The thrust of their recommendations was to 
adopt the organisational structure found in the best civilian hospitals, to strengthen the authority of the Matron-in-Chief, putting the management of Army nursing under a newly constituted Nursing Board, and more in the control of senior nurses. Some members of the military found these ideas abhorrent and campaigned against them. Lieutenant-Colonel Alfred Keogh cautioned the Committee that in his opinion he did not believe a group of women could be trusted with the power they were going to be afforded under the new organisational structure. Women, he contended, were too likely to indulge in 'petty spites' and 'give it hot' to any nurse who usurped their position when going out into society, for example within garrisons to enjoy 'tea, dances and dinner parties'. They could not be trusted to behave rationally in the face of social pleasures and required guidance and support. Keogh concluded, 'Women have not the same feeling about these things. Theoretically it may be all right, but practically, in a garrison town, where these nurses are very much in society, going out to dinner parties, and all the rest of it, if the Matron-in-Chief is not the head in the society they are in, and goes amongst them and takes the lead', then he assumed that she could not be trusted to distance herself from perceived social slights and would behave in a 'spiteful' manner towards her fellow nurses. ${ }^{79}$

This was not a new complaint against women, but reflected prevalent views that women were incapable of organising themselves. They were held to be physically and intellectually inferior and therefore unable to deal with the realities of the male-dominated public sphere where all major decisions were made. ${ }^{80}$ Hence the issue for the 'new woman' was not simply how to gain equal rights with men, but how to obtain recognition for their achievements in a man's world in their own right, this being problematic when faced with the opposition of powerful men such as Alfred Keogh. ${ }^{81}$ For Keogh and his ilk, this 'power grab' on the part of nurses was part and parcel of the 'new woman' movement, another example of women overstepping the mark and setting themselves up against accepted behavioural norms. Keogh was ultimately unsuccessful, and in 1902, as the Second Anglo-Boer War was ending, a new Army nursing service was born under the presidency of Queen Alexandra, and named in her honour: the Queen Alexandra's Imperial Military Nursing Service (QAIMNS), which delivered most of the objectives the nurses had been fighting for. 
Once female nurses were given a permanent place in the sphere of war it was necessary to ensure that there would be no future scandals at 'the front' regarding nurses' behaviour, and that they would not behave in any way which might serve as a distraction to the medical men and officers. ${ }^{82}$ The nurses who had travelled to southern Africa with a combined sense of patriotic duty and a desire for new experiences had found themselves with no head of nursing and a lack of defined control. ${ }^{83}$ Following accusations of 'frivolity', there was a need not only for reform, but also for consideration of the future social exploits of nurses during periods of war and peace. An article entitled 'Nurses, you must not dance!', written by John Strange Winter in the early years of the new service's creation, relayed recent discussions in Parliament regarding the testing question of whether Army nurses should be permitted to dance in their off-duty hours. ${ }^{84}$ The question was raised in the House, and Mr Haldane, Secretary of State for War, replied that he had consulted the Nursing Board on the matter and had been advised that:

The Nursing Board requires for His Majesty's nursing service gentlewomen who are devoted first and foremost to their work for its own sake and for the sake of their patients, and who will, therefore, desire to live quietly and unostentatiously without looking for much gaiety. ${ }^{85}$

It would appear that henceforth nurses would be required to behave respectably and that those social exploits enjoyed by nurses such as Dora Harris, who danced till 2 a.m. during a night shift, or Emily Wood, buying lace for new capes to attend a ball, would no longer be tolerated.

Yet, despite this penchant to 'go out into society' during their wartime service, army medical officials still acknowledged the vital importance of good nursing and nurses. ${ }^{86}$ Wartime service offered women the prospect of travelling abroad to experience 'every exotic detail' of war, which for many was viewed as 'a once-in-a-lifetime' opportunity which had previously been the exclusive domain of men. ${ }^{87}$ The behaviour which prompted accusations of 'frivolling' was the result perhaps of the combination of a relaxation of the social constraints at home and the unimaginable pressures during their shifts: 'frivolling' was a letting-off of steam during their off-duty time. This war has been described as the last of the gentlemen's wars, embodying Victorian 
ideals of chivalry and a country-club atmosphere of polo parties and balls, which provided ample opportunity for nurses to escape the horrors of the wards. ${ }^{88}$

The accusations of frivolity, so pointedly made against nurses in the early phase of the Second Anglo-Boer War, served to support the arguments for enhanced authority over nurses serving in the sphere of war. The formation of QAIMNS in 1902 provided the organisational structure through which authority and discipline could be implemented. The permanent presence of nurses in war necessitated a new hierarchy of authority and the internal control of nurses by nurses. Although this new hierarchy remained ultimately subordinate to male authority, the 'problem' of nurses during the Second Anglo-Boer War appears to have been an important facilitator in the reform of military nursing.

\section{Conclusion}

On their arrival in South Africa, nurses appeared to exploit new-found freedoms to enjoy their off-duty hours alongside male colleagues, while still demonstrating their worth as expert practitioners. However, the social exploits of nurses in South Africa prompted anxieties surrounding the respectability and general behaviour of female nurses; it became obvious that if the 'good nurse' image was to be upheld, it was imperative that scandals which could damage the 'self-sacrificing angels' imagery should be avoided. ${ }^{89}$ Summers has claimed that no other group of women 'received anything like the measure of public distinction and exposure accorded to nurses', and the body of nurses was determined to protect their hard-won and newly elevated position in society. ${ }^{90}$ It is also apparent that such concerns guided reform of the regulations which would control the lifestyles of future Army nurses, with strict guidance on social intercourse in place by the First World War. ${ }^{91}$

The Second Anglo-Boer War provided an opportunity for British nurses to contribute to the maintenance of Empire and publicly demonstrate their worth as professionals, as women and arguably as citizens eligible for the vote. ${ }^{92}$ Those nurses who demonstrated the superiority of their knowledge and skills provided further evidence for the need for State registration, to ensure that those with acknowledged training could be distinguished from 'amateurs'. And despite 
concerns over nurses' social exploits and behaviour, historian Laura Nym Mayhall has argued that campaigners for women's suffrage, such as Millicent Garrett Fawcett (president of the National Union of Women's Suffrage Societies), believed the Second Anglo-Boer War provided British women with the ideal opportunity 'to demonstrate their fitness for citizenship by their willingness to perform services for the nation and empire in its hour of need. ${ }^{93}$ In addition it may be argued that the desire by nursing's leaders to curb nurses' 'frivolities', also (probably inadvertently) made them instrumental proponents of imperialism. Arguments surrounding women's contribution to this war and thus their rights to citizenship continued into the First World War, with claims that 'citizenship was itself validated by participation in the war effort, which in turn gave women confidence to make claims for greater equality. ${ }^{94}$

It could be argued that while the project to professionalise nursing was buoyed by the work of nurses during the Second Anglo-Boer War, paradoxically, concerns over their behaviour and their social exploits were also key to the establishment of a more professional Army nursing service, and made a significant contribution to the drive for nurse registration at home. The establishment of the QAIMNS resulted in clear definition and demarcation of the work of the matron and sisters and their nurses, which became enshrined in the Regulations for Admission to the Queen Alexandra's Imperial Military Nursing Service. The regulations included specific guidance on the nurses' clinical role and duties and, as in civilian hospitals, extended into control of their personal lives, for instance dictating the time that nurses were to retire to bed and indeed to turn out their lights. ${ }^{95}$ It also provided further evidence that one of the main aims on the establishment of the QAIMNS was to bring female nurses under the control of one single hierarchy, subject to a clear set of rules.

It is apparent that by the beginning of the First World War, only twelve years later, control over nurses' social exploits was firmly in place, with one nurse noting that, 'The rules regulating the social life of the Sisters are very severe and social intercourse with the Medical Officers is prohibited. ${ }^{36}$ The experiences of the Second Anglo-Boer War had produced a complete overhaul of Army nursing services with ramifications for all British nurses who ventured into the theatre of war in the future. 


\section{Notes}

1 I would like to offer my sincere thanks and gratitude to Dr Sue Hawkins and Dr Helen Sweet for their excellent editorial input and additions. An earlier, shortened version of this chapter was published in the Bulletin of the UK Association for the History of Nursing, Issue 2, November 2013. Published here by kind permission of the Editor of the Bulletin.

2 S. Mitchell, Daily Life in Victorian England (Westport, CT: Greenwood Publishing Group, 1996), p. 263.

3 T. Pakenham, The Boer War (London: Abacus, 1992), p. xxi; F. R. Van Hartesveldt, The Boer War: Historiography and Annotated Bibliography (Westport, CT: Greenwood Press, 2000), pp. 2-3; W. A. Murray, 'Towards world war 1871-1914', in G. Parker (ed.), The Cambridge Illustrated History of Warfare (Cambridge: Cambridge University Press, 2008), pp. 242-65, p. 249.

4 Pakenham, The Boer War, p. 19.

$5 \mathrm{H}$. Sweet, "Wanted: 16 nurses of the better educated type": provision of nurses to South Africa in the late nineteenth and early twentieth centuries', Nursing Inquiry, 11:3 (September 2004), 176-84.

6 Sweet, "Wanted: 16 nurses of the better educated type".

7 Medical Act No. 34 (1891), passed by the Cape Colonial Government and reinforced by a similar act in Natal in 1899 at the commencement of the Second Anglo-Boer War.

8 K. Spires, 'Nurses in the Boer War (1899-1902)' (PhD dissertation, London South Bank University, 2013), pp. 213-15.

9 A. M. Rafferty, 'The seductions of history and the nursing diaspora', Health and History, 7:2 (2005), 2-16.

10 Rafferty, 'The seductions of history'.

11 F. Nightingale, Subsidiary Notes as to the Introduction of Female Nursing into Military Hospitals in Peace and War. Presented to the Secretary of State for War (Thoughts submitted as to an eventual Nurses' Provident Fund) (London: Harrison and Sons, 1858), pp. 23-4.

12 M. E. Baly, Florence Nightingale and the Nursing Legacy (London: Croom Helm, 1986), p. 105.

13 B. C. Hacker, 'Reforms, nurses and ladies in uniform: the changing status of military women, c. 1815-1914', in B. C. Hacker and M Vining (eds), The Companion to Women's Military History (Leiden: Brill, 2012), pp. 137-88.

14 E. Haldane, The British Nurse in Peace and War (London: John Murray, 1923), p. 165; S. Bingham, Ministering Angels (London: Osprey, 1979), pp. 111-15; A. Summers, Angels and Citizens: British Women as Military Nurses, 1854-1914 (London: Routledge and Kegan Paul, 1988), p. 105.

15 'The Nursing Board: Queen Alexandra's Imperial Military Nursing Service. An address by the chairman, Surgeon General W. Taylor ... on the History of the Army Nursing Service', April 1902, The National Archives, 
WO243/20. Available online at www.scarletfinders.co.uk/17.html (accessed 8 November 2014).

16 Anonymous, 'The Army Nursing Reserve', The Times (20 May 1897), p. 10.

17 Princess Christian was the third daughter and fifth child of Queen Victoria. Her son, Prince Christian Victor, died of enteric fever at Pretoria during the Anglo-Boer War. J. Van der Kiste, 'Helena, Princess [Princess Christian of Schleswig-Holstein] (1846-1923)', Oxford Dictionary of National Biography (Oxford: Oxford University Press, 2004), www.oxforddnb.com/view/article/41067 (accessed 31 January 2014).

18 N. G. Gooding, Honours and Awards to Women to 1914 (London: Savannah, 2007), p. 132; H. Rappaport, No Place for Ladies: The Untold Story of Women in the Crimean War (London: Aurum Press, 2008), pp. 194-8.

19 Anonymous, 'The New Army Nursing Reserve', Daily Telegraph (31 March 1897), in Dame Sidney Brown, Press Cuttings, QA/PE/1/7/BROW, Army Medical Services Museum (AMS), Aldershot.

20 J. Lewis, Women and Social Action in Victorian and Edwardian England (Aldershot: Edward Elgar, 1991), p. 11; A. Summers, 'Ministering angels: Victorian ladies and nursing reform', History Today, 39:2 (1989), 37.

21 R. Dingwall, A. M. Rafferty and C. Webster, An Introduction to the Social History of Nursing (London: Routledge, 1988), p. 35. See also: J. Piggott, Queen Alexandra's Royal Army Nursing Corps (London: Leo Cooper, 1975), p. 35; Summers, Angels and Citizens, p. 178; B. Best and K. Stossel, Sister Janet: Nurse and Heroine of the Anglo-Zulu War 1879 (Barnsley: Pen and Sword Books, 2006), p. 157.

22 J. E. Schultz, Women at the Front Hospital Workers in Civil War America (Chaple Hill: University of North Carolina Press, 2004), p. 47.

23 Mitchell, Daily Life in Victorian England, p. 263; Rappaport, No Place for Ladies, pp. 194-8.

24 The editor of Nursing Record used the term 'frivol' to describe some nurses whose behaviour in southern Africa during the war was a cause for concern: 'These women, are known as "frivols", and have brought no end of discredit upon the nursing profession as a whole. Gadding, junketing, riding, driving, racing, dancing, picnicking, "a high old time," is the unblushing aim of the "frivol". 'Echoes', Nursing Record, 28 (4 January 1902), 13; Summers, Angels and Citizens, p. 199.

25 For discussions on respectability and women in British society at the end of the century see: F. M. L. Thompson, The Rise of Respectable Society: A Social History of Victorian Britain 1830-1900 (London: Fontana Press, 1988); S. O. Rose, Limited Livelihoods: Gender and Class in Nineteenth-Century England (London: Routledge, 1992); A. Summers, Female Lives, Moral States: Women, Religion and Public Life in Britain 1800-1930 (London: Threshold Press, 2000); C. Judd, Bedside Seductions: Nursing and the Victorian Imagination, 1830-1880 (Basingstoke: Macmillan, 1998), among others. 
26 J. Hallam, Nursing the Image: Media, Culture and Professional Identity (London: Routledge, 2000), p. 20.

27 P. Levine, Victorian Feminism 1850-1900 (London: Hutchinson Education, 1987), p. 129; T. M. Group and J. I. Roberts, Nursing, Physician Control, and the Medical Monopoly: Historical Perspectives on Gendered Inequality in Roles, Rights, and Range of Practice (Bloomington, IN: Indiana University Press, 2001), p. 176; A. S. Fell, 'Fallen angels? The Red Cross nurse in First World War discourse', in M. Allison and Y. Rocheron (eds), The Resilient Female Body: Health and Malaise in Twentieth-Century France (Berne, Switzerland: Peter Lang AG, 2007), p. 39.

28 S. Hawkins, Nursing and Women's Labour in the Nineteenth Century: The Quest for Independence (Abingdon: Routledge, 2010); B. Abel-Smith, A History of the Nursing Profession (London: Heinemann, 1960).

29 S. McGann, The Battle of the Nurses (Harrow: Scutari Press, 1992).

30 M. Goodnow, Nursing History (Philadelphia and London: W. B. Saunders Company, 1944), p. 324; A. M. Rafferty, The Politics of Nursing Knowledge (London: Routledge, 1996), p. 71.

31 Goodnow, Nursing History, p. 463.

32 Rafferty, The Politics of Nursing Knowledge, p. 71.

33 L. L. Dock, 'The progress of registration', American Journal of Nursing, 6:5 (1906), 297; B. Gordon, 'Nursing conditions in South Africa', American Journal of Nursing, 26:12 (1926), 935; L. R. Seymer, A General History of Nursing (London: Faber and Faber, 1932), pp. 124-5; Goodnow, Nursing History, p. 452; C. Searle, The History of the Development of Nursing in South Africa 1652-1960 (Cape Town, SA: Struik, 1965), p. 164; Shula Marks, Divided Sisterhood: Race, Class and Gender in the South Africa Nursing Profession (Basingstoke: Macmillan, 1994), p. 15; Rafferty, The Politics of Nursing Knowledge, p. 76; A. Young, C. F. Van Niekerk and S. Mogotlane (eds), Juta's Manual of Nursing (Cape Town, SA: Juta and Co. Ltd, 2003), p. 7; M. Currie, Fever Hospitals and Fever Nurses. A British Social History of Fever Nursing: A National Service (Abingdon: Routledge, 2005), p. 40.

34 The Needham Papers, NCUACS 54/3/95 File A.624, Cambridge University Archives.

35 E. C. Laurence, A Nurse's Life in War and Peace (London: Smith, Elder and Co., 1912), p. 282.

36 'The Nursing Board: Queen Alexandra's Imperial Military Nursing Service'.

37 H. Dampier, "The treatment of "Everyday Life" in memory and narrative of the concentration camps of the South African War, 1899-1902', in N. Kelly, C. Horrocks, K. Milnes, B. Roberts and D. Robinson (eds), Narrative, Memory and Everyday Life (Huddersfield: University of Huddersfield, 2005), p. 188.

38 Dampier, 'The treatment of "Everyday Life"', p. 188; E. Van Heyningen, " "Fools rush in": writing a history of the concentration camps of the South African War', Historia, 55:2 (2010), 19. 
39 See, for instance, H. Brown, The Truest Form of Patriotism: Pacifist Feminism in Britain, 1870-1902 (Manchester: Manchester University Press, 2003) and P. M. Krebs, " "The last of the gentlemen's wars”: women in the Boer War concentration camp controversy', History Workshop Journal, 33:1 (1992), 38-56, for a discussion of the role of feminists such as Millicent Fawcett, Josephine Butler and Emily Hobhouse in the investigation of the use of concentration camps in the Boer War.

40 E. Van Heyningen, 'Women and gender in the South African War, 1899-1902', in N. Gasa (ed.), Women in South African History (Cape Town, SA: HSRC Press, 2007), p. 96.

41 Van Heyningen, 'Women and gender', p. 96.

42 Van Heyningen, 'Women and gender', p. 96.

43 E. Van Heyningen, The Concentration Camps of the Anglo-Boer War: A Social History (Auckland Park, SA: Jacana, 2013).

44 K. Brown, Fighting Fit: Health, Medicine and War in the Twentieth Century (Stroud: The History Press, 2008), p. 17. The high prevalence of typhoid fever features in the accounts of Dora Harris, Manuscript Diary (15 April 1900) 1976-11-17, National Army Museum (NAM), London; Edith Hancock, 'Correspondence with her Aunt Eliza (23.05.1900)', AMS; A. N. R., 'Our foreign letter Chieveley, Natal', Nursing Record, 24 (16 June 1900), 483; Anonymous, 'War notes', Nursing Notes: A Practical Journal for Nurses, 13 (1 July 1900), 91.

45 Brown, Fighting Fit, p. 18.

46 A. Knyvett Gordon, 'Notes on practical nursing', Nursing Record 26 (2 March 1901), 165.

47 D. L. Harris, 'Manuscript Diary' (25 August 1900) 1976-11-17, NAM.

48 Harris, 'Manuscript Diary' (23 October 1900).

49 E. J. Wood, 'Boer War Nurse's Journal' (26 July 1900), MS. 6034 Wellcome Library (WL), London.

50 Wood, 'Boer War Nurse's Journal' (26 April 1900). This desire of nurses to explore their surroundings was not restricted to the Boer War. Janet Watson has highlighted similar desire to explore in the diary of a First World War nurse, Alice Slythe, who took every opportunity she could to venture out from her base in France to explore the surrounding countryside in her attempts to get a close-up view of the Front Line. J. S. K. Watson, 'A sister's war: the diaries of Alice Slythe', in A. S. Fell and C. E. Hallett (eds), First World War Nursing: New Perspectives (Abingdon: Routledge, 2013), pp. 103-22.

51 Wood, 'Boer War Nurse's Journal' (13 September 1900).

52 E. Hancock, 'Correspondence with her sister Ellie (18 May 1900)', folder labelled: QA Museum, 'Miss Hancock's Letters', uncatalogued, AMS.

53 Rappaport, No Place for Ladies, p. 2, p. 105.

54 W. F. Neff, Victorian Working Women: An Historical and Literary Study of Women in British Industries and Professions 1832-1850 (London: George 
Allen and Unwin Ltd, 1966), p. 74; Dingwall et al., An Introduction to the Social History of Nursing, p. 58; L. Pykett, 'Portraits of the artist as a young woman: representations of the female artist in the New Woman fiction of the 1890s', in N. D. Thompson (ed.), Victorian Women Writers and the Woman Question (Cambridge: Cambridge University Press, 1999), p. 144; J. Hedgecock, The Femme Fatale in Victorian Literature: The Danger and the Sexual Threat (New York: Cambria Press, 2008), p. 72; D. Gorham, The Victorian Girl and the Feminine Ideal (Abingdon: Routledge, 2013), pp. 101-2.

55 I. Hay, One Hundred Years of Army Nursing: The Story of the British Army Nursing Services from the Time of Florence Nightingale to the Present Day (London: Cassell and, 1953), p. 58; K. Spires, 'Ethel Hope Becher', Boer War Nurses Database, http://britisharmynurses.com/wiki/index. php?title=Special:IframePage/Database (accessed 12 February 2014).

56 Ethel Hope Becher, 'Correspondence with Sydney Holland', LH/N/7/6, The London Hospital Archives (LHA).

57 Becher, 'Correspondence with Sydney Holland'.

58 Laurence, A Nurse's Life, p. 272.

59 Laurence, A Nurse's Life, p. 282.

60 Laurence, A Nurse's Life, p. 282.

61 Laurence, A Nurse's Life, p. 282.

62 For a discussion of how the conjunction of nursing and female respectability was problematic to late Victorian society see Hawkins, Nursing and Women's Labour, ch. 1, pp. 21-7. For more general discussions of women and respectability in Victorian society see, for instance, C. Dyhouse, Girls Growing Up in Late Victorian and Edwardian England (London: Routledge and Kegan Paul, 1981); L. Vallone, Discipline of Virtue: Girls' Culture in the Eighteenth and Nineteenth Centuries (New Haven, CT: Yale University Press, 1995); E. Trudgill, Madonnas and Magdalens (London: Heinemann, 1976).

63 L. Faderman, Surpassing the Love of Men: Romantic Friendship and Love between Women from the Renaissance to the Present (London: The Women's Press, 1985), p. 159.

64 B. Harrison, 'Women and health', in June Purvis (ed.), Women's History: Britain, 1850-1945 (London: UCL Press, 1995), pp. 157-92; Rose, Limited Livelihoods; J. Newton, M. Ryan and J. Walkowitz (eds), Sex and Class in Women's History (London: Routledge and Kegan Paul, 1983), pp. 16-71.

65 E. Priestley, 'Nurses à la mode', Nineteenth Century, 41:239 (1897), 31.

66 Rafferty, 'The seductions of history'.

67 Mitchell, Daily Life in Victorian England, p. 269.

68 Nisbet does not make clear who Mr Thunder was, but it would seem likely that he was a medic or an English colonist.

69 K. Nisbet, 'Correspondence with Major James Watson (September 1901)', 8412-4-112, NAM. Emphasis in original. 
70 Nisbet, 'Correspondence with Major James Watson (18 March 1901)', 8412-4-75, NAM.

71 Nisbet, 'Correspondence with Major James Watson (18 March 1901)'.

72 Nisbet, 'Correspondence with Major James Watson (28 September 1901)', 8412-4-116, NAM. Emphasis in original.

73 G. Best, The History of British Society: Mid-Victorian Britain 1851-1875 (London: Weidenfeld and Nicolson, 1971), p. 257.

74 P. Branca, Silent Sisterhood: Middle-Class Women in the Victorian Home (London: Croom Helm, 1975), p. 7.

75 H. Morten, How to Become a Nurse and How to Succeed (London: Scientific Press, 1893), p. 9; Hallam, Nursing the Image, pp. 14, 20.

76 E. C. E. Luckes, General Nursing (London: Kegan Paul, Trench, Trubner and Co., 1900), p. 21.

77 A. Summers, 'Images of the nineteenth-century nurse', History Today, 34:12 (1984), 40. There are some interesting letters in the Nursing Record towards end of the nineteenth century about the behaviour of nurses in London, from parents who state they would never let their daughters join such a disreputable profession, indicating that there were problems at home, too. See Hawkins, Nursing and Women's Labour, p. 145.

78 Summers, Angels and Citizens, p. 198.

79 'Discussion of the War Office Committee on the Reorganisation of the Army Medical and Army Nursing Services (22 July 1901)', 6/1956 A700, p. 138, AMS.

80 G. J. Romanes, 'Mental differences between men and women', Nineteenth Century, 21:122 (1887), 654-5; B. Theron, 'Victorian women, gender and identity in the South African War: a review', UNIS KLEIO, 38:1 (2006), 3.

$81 \mathrm{~J}$. Park, 'Women of their time: the growing recognition of the second sex in Victorian and Edwardian England', Journal of Social History, 21:1 (1987), 49.

82 E. C. Briggs, The Staff Work of the Anglo-Boer War, 1899-1901 (London: G. Richards, 1901), p. 15.

83 L. Holcombe, Victorian Ladies at Work: Middle-Class Working Women in England and Wales 1850-1914 (Devon: David and Charles, 1973), p. 82.

84 Dame S. Brown, Press cuttings, Ideas, 20 December 1906, AMS. John Strange Winter is the pseudonym for a prolific late nineteenth-century female novelist, Henrietta Eliza Vaughan Stannard. Owen R. Ashton, 'Stannard, Henrietta Eliza Vaughan (1856-1911), Oxford Dictionary of National Biography (Oxford: Oxford University Press, 2004), www.oxforddnb.com/view/article/ 36251 (accessed 8 December 2014).

85 Dame S. Brown, Press cuttings, Ideas, 20 December 1906.

86 Summers, Angels and Citizens, p. 197, p. 218; E. Taylor, Wartime Nurse: One Hundred Years from the Crimea to Korea 1854-1954 (London: ISIS, 2001), p. 69. 
87 Summers, Angels and Citizens, p. 203; J. Lee, 'A nurse and a soldier: gender, class and national identity in the First World War adventures of Grace McDougall and Flora Sandes', Women's History Review, 15:1 (2006), 84; Rappaport, No Place for Ladies, p. 93.

88 Krebs, "The last of the gentlemen's wars"'; Van Hartesveldt, The Boer War, p. 32; Rappaport, No Place for Ladies, pp. 194-8.

89 Hallam, Nursing the Image, p. 20.

90 Summers, 'Images of the nineteenth-century nurse', 40.

91 Regulations for Admission to the Queen Alexandra's Imperial Military Nursing Service (QAIMNS) Army Orders (London: HMSO, 1902), HI/ST/NC15/16/2, London Metropolitan Archives (LMA), pp. 8-9; Miss Bickmore, 'Ambulance trains, France', in A. Powell (ed.), Women in the War Zone: Hospital Service in the First World War (Stroud: The History Press, 2009), p. 90.

92 A. Summers, 'Women as voluntary and professional military nurses in Great Britain 1854-1914' (PhD dissertation, Open University, 1985), pp. 231-2; J. M. Gould, 'The Women's Corps: the establishment of women's military services in Britain' (PhD dissertation, University of London, 1988), p. 19; M. Lefebvre, 'Feminism and the challenge of war: responses of the British women's suffrage movement to the Great War' ( $\mathrm{PhD}$ dissertation, University of London, 2009), pp. 53-4.

93 L. E. Nym Mayhall, The Militant Suffrage Movement: Citizenship and Resistance in Britain, 1860-1930 (New York: Oxford University Press, 2003), p. 29.

94 E. Breitenbach, 'Scottish women's organizations and the exercise of citizenship c. 1900-c. 1970', in E. Breitenbach and P. Thane (eds), Women and Citizenship in Britain and Ireland in the Twentieth Century: What Difference Did the Vote Make? (London: Continuum UK, 2010), p. 73.

95 Regulations for Admission to the QAIMNS.

96 Bickmore, 'Ambulance trains, France', p. 90. 